Soviet applied research

\section{Broader view demanded}

SOVIET industrial research institutes are wasting time on minor improvements to existing technologies at the expense of ideas that could lead to fundamental innovations, a Pravda editorial alleged last week. In many cases, the newspaper said, the institutes cannot resist the "commercial contract element" and are inundated by a flood of minor projects. As a result, the proportion of genuine research work done in engineering-oriented institutes has decreased over the past decade by a factor of three.

During the Brezhnev era, it was standard practice to attribute Soviet technological lags to delays in implementing research results. At the time, this explanation seemed entirely reasonable, since the Soviet system of production targets runs into difficulties if innovation involves major retooling; factory managers are not keen on shutdowns which bring production deficits and the loss of bonuses.

Although, during the past fifteen years, there have been several attempts to involve scientists more closely in the industrial process, these have aimed at forming closer links between scientific institutes and local industry; often, existing institutes were combined into a regional "science centre" so as to provide a research base for local production. Direct contracts between industry or agriculture and such institutes or centres were advocated as an effective method of speeding applied research.

Now a reverse swing is under way. While spending time, money and laboratory space on local contracts, the institutes have fallen behind in their major research commitments. During the past two years, Pravda says, only 82 industrial pilot plants were completed out of a planned 127 , while the Ministry of Agriculture and the State Supply Service (Gossnab) failed to complete a single project on time. Six projects of the Ministry of Petroleum Production and five each of the Ministry of Fisheries and the Ministry of Chemical Machinery due for completion this year are now irretrievably delayed. And in 40 per cent of cases, the delays were due to waste of efforts on "minor research".

The article, with its call for "ministries, departments and party committees" to "strengthen their leadership", over research organizations, follows the usual pattern of a new policy drive, which will almost certainly result in a considerable cutback of minor contracts. The purpose of the turnabout, however, seems to be not so much of increasing central control over research decision-making, but of inculcating among the heads of research teams a greater awareness of the topicality and scientific value of proposed investigations.

Biotechnology

\title{
Cash pile at Biogen
}

AMONG biotechnology companies, Biogen NV is the most like a bank. In its annual report for 1982, Biogen says that its financial assets amounted to $\$ 57.5$ million, much more than its long-term debt of $\$ 5.8$ million at the end of the year. Since then it has raised a further $\$ 54$ million by its public sale of stock on 22 March (see Nature 14 April, p.565).

Part of the explanation of the company's cash position is that it has been able to finance the construction of its laboratory in Cambridge, Massachusetts, with the help of two low interest bonds arranged by the Massachusetts Industrial Finance Agency in 1981 , which provided $\$ 4.5$ million. During 1982, interest on the company's financial assets amounted to $\$ 8.5$ million, two thirds of what it earned by means of payments for research and development carried out.

Paradoxically, Biogen's cash mountain may explain why the share price has drifted downwards from the issue price of $\$ 23$ ten weeks ago. While a large proportion of Biogen's income is investment income, investors may think it preferable to put their money with an institution specialized in investment rather than in biotechnology.

Research and development remains the largest item of expenditure (amounting to $£ 18.4$ million in 1982) and spending under this heading will continue to increase for the foreseeable future. The total loss on Biogen's operations last year was $£ 4.7$ million (\$0.8 million in 1981) and the company says that annual losses are also an integral part of its plans for the years ahead.

Indeed, the accumulated loss is now almost exactly $\$ 10$ million, while Biogen has also invested more than $\$ 1.5$ million in securing patents on its products. These costs are carried in the balance sheet as capital assets whose value is written down each year to allow for the shortening life of the patents. The pattern of Biogen's programme remains concentrated on the exploitation of microbially engineered interferons (which are being tested clinically for use in multiple sclerosis, genital herpes and various forms of cancer, not to mention the common cold), vaccines and blood factors. An agreement to produce interleukin-2 in conjunction with a Japanese company was announced earlier this year.

The spread of the company's research contracts remains somewhat narrow. In 1982, 44 per cent of research income came from the Schering Corporation and 37 per cent from the Japanese company Shionogi Ltd. The annual report emphasizes that research income is inherently unpredictable and that 75 per cent of its income in 1982 came from research projects already completed so that further income (from royalties) will not arise until clinical testing is complete.

Biogen's latest project, announced last week, is a partnership to develop a process for making human tumour necrosis factor in conjunction with Suntory Ltd, the Japanese whisky and pharmaceutical manufacturer. This project will be based on a new laboratory called BIOGENT, at Ghent in Belgium, under the direction of Professor Walter C. Fiers, professor of molecular biology at the University of Ghent and a member of the scientific board of Biogen.

\section{Nature index of biotechnology stocks}

\begin{tabular}{|c|c|c|c|c|c|}
\hline $\begin{array}{l}\text { 12-Month } \\
\text { high }\end{array}$ & $\begin{array}{l}\text { 12-Month } \\
\text { low }\end{array}$ & Company & $\begin{array}{l}\text { Close } \\
\text { previous } \\
\text { month }\end{array}$ & $\begin{array}{l}\text { Close } \\
27 \text { May }\end{array}$ & Change \\
\hline $901 / 2$ & $451 / 4$ & A.B. Fortia (Sweden) & $761 / 4$ & 82 & $+53 / 4$ \\
\hline $231 / 4$ & $161 / 4$ & Biogen (USA) & $181 / 4$ & $163 / 4$ & $-11 / 2$ \\
\hline 6 & 3 & Bio-Logicals (Canada) & $53 / 4$ & $43 / 4$ & -1 \\
\hline 13 & $71 / 4$ & Bio-Response (USA) & $10 \%$ & $10 \% / 8$ & $+1 / 4$ \\
\hline 19 & $11 \mathrm{~s} / \mathrm{s}$ & Cetus (USA) & 16 & $161 / 2$ & $+1 / 2$ \\
\hline $141 / 2$ & $91 / 2$ & Collaborative Research (USA) & $10 \%$ & $91 / 2$ & $-1 \frac{1}{8}$ \\
\hline $397 / 8$ & 15 & Damon (USA) & $34 \frac{5}{x}$ & $373 / 4$ & $+3 \frac{1}{8}$ \\
\hline 41 & $241 / 2$ & Enzo-Biochem (USA) & $371 / 4$ & $393 / 4$ & $+21 / 2$ \\
\hline $18^{7} / 8$ & $107 / 8$ & Flow General (USA) & $12 \frac{1}{x}$ & $131 / 4$ & $+1 \frac{1}{8}$ \\
\hline $461 / 2$ & $261 / 8$ & Genentech (USA) & 41 & $42 \frac{1}{2}$ & $+11 / 2$ \\
\hline $131 / 2$ & $83 / 4$ & Genetic Systems (USA) & $103 / 4$ & $123 / 4$ & +2 \\
\hline $191 / 2$ & $12 \frac{7}{x}$ & Genex (USA) & $15 \% / x$ & $181 / 2$ & $+27 / 8$ \\
\hline $271 / 2$ & $211 / 4$ & Hybritech (USA) & $271 / 4$ & $263 / 4$ & $-1 / 2$ \\
\hline $221 / 4$ & $133 / 4$ & Molecular Genetics (USA) & $163 / 4$ & 22 & $+51 / 2$ \\
\hline $231 / 4$ & 16 & Monoclonal Antibodies (USA) & $171 / 2$ & $191 / 4$ & $+13 / 4$ \\
\hline $65 \%$ & 42 & Novo Industri A/S (Den) & $571 / 4$ & $603 / 8$ & $+3 \frac{1}{8}$ \\
\hline
\end{tabular}

Closing prices are for the last Friday of the month. For over-the-counter stocks, bid price is quoted; for stocks on the American and New York exchanges, the transaction price. The index stood at 223 on 27 May, compared with 213 a month earlier. Data from E.F. Hutton, Inc. 